\title{
The uses of Kenyan aloes: an analysis of implications for names, distribution and conservation
}

\author{
Charlotte S. Bjorå ${ }^{*}$ (D), Emily Wabuyele 2,3 , Olwen M. Grace ${ }^{4}$ Inger Nordal ${ }^{2}$ and Leonard E. Newton ${ }^{3}$
}

\begin{abstract}
Background: The genus Aloe is renowned for its medicinal and cosmetic properties and long history of use. Sixty-three Aloe species occur in Kenya, of which around $50 \%$ are endemic. Several species of aloes are threatened with extinction and knowledge about their use is of major importance for sound conservation strategies. The main aims of this study were to assess the biocultural value of Aloe in Kenya by documenting local uses of aloes and evaluating how the vernacular names reflect the relative importance in different ethnic groups.
\end{abstract}

Methods: Ethnobotanical and ethnotaxonomical data were collected using field observations and semi-structured interviews. Information was collected by interviewing 63 respondents from nine different ethnic groups, representing different ages, gender and occupations. Statistical analyses were performed using R version 3.1.2.

Results: A total of 19 species of Aloe were found in the study area, of which 16 were used. On the generic level Aloe was easily distinguished. At species level, the local and scientific delimitation were almost identical for frequently used taxa. Aloe secundiflora, with 57 unique use records was the most important species. The two most frequently mentioned Aloe treatments, were malaria and poultry diseases. In our study area neither age nor gender had a significant influence on the level of knowledge of Aloe use. Finally, no correlation was found between extent of use and people's perception of decrease in local aloe populations. The aloes are highly appreciated and are therefore propagated and transported over large areas when people relocate.

Conclusion: Biocultural value is reflected in the ethnotaxonomy of Aloe in Kenya. Different ethnic groups recognise their most-valued Aloe at the genus level as "the aloe" and add explanatory names for the other species, such as the "spotted aloe" and the "one-legged aloe". Widespread species of Aloe have the highest number of uses. There is no obvious correlation with high use and decrease in abundance of aloes locally, and we found no compelling evidence for local uses causing devastating damage to populations of the 19 species in use, whereas habitat loss and commercial harvesting appear to be of urgent concern for these important plants.

Keywords: Aloe, Ethnobotany, Ethnotaxonomy, Folk use, Conservation, Kenya, Plant use

\section{Background}

The genus Aloe L. is renowned for its medicinal and cosmetic properties that have been exploited over millennia [1-4], including the popular species Aloe vera (L.) Burm.f. which was recorded in use as early as $400 \mathrm{BCE}$ [5]. The genus contains around 550 species [6] but only a few species feature in international trade of any

\footnotetext{
*Correspondence: charlotte.bjora@nhm.uio.no

${ }^{1}$ Natural History Museum, University of Oslo, P.O. Box 1172, Blindern 0318 Oslo, Norway

Full list of author information is available at the end of the article
}

significance [7], i.e. Aloe vera, A. perryi Baker, A. ferox Mill. and $A$. arborecens Mill.

Kenya is known for its high diversity of aloes [8-11]. Carter et al. [8] reported 59 species in Kenya, and since then four more species have been described [12, 13]. Due to their multi-use nature, Kenyan aloes have in been harvested at household level over many years mainly for use as herbal remedies in combination with other plants [14]. The commercial exploitation of aloes in Kenya was first reported in the 1960s, when substantial amounts of wild-harvested leaf extracts, mainly of A. secundiflora 
Engl., were exported to the USA [15]. Since then, several similar incidents of wild harvested aloe extracts for sale have been reported [16, 17]. In 1986, the then president of Kenya declared a ban on harvesting wild-growing aloes in recognition of the potentially devastating effects of harvesting on the plants and their habitats [18]. However, the presidential decree was not translated into a legal instrument and was largely ignored [16]. In some areas where the law was adhered to, it led to more harm than protection [19]: rather than defoliating plants in natural populations and allowing recovery, plants of Aloe secundiflora were dug up and re-planted in "plantations". In 2007 stakeholders consulted widely and came up with Aloe Utilization guidelines that were gazetted by the Kenya government at the end of 2007 as subsidiary legislation [20], bridging the legal gap in the aloe industry.

In Kenya today, the species $A$. secundiflora, A. turkanensis Christian, A. rivae Baker, A. calidophila Reynolds, and A. scabrifolia L.E.Newton \& Lavranos are reported to be commercially exploited for aloe bitter exudate [17, 21]. A. scabrifolia and A. turkanensis [16] are particularly threatened by organized collecting activities coordinated by dealers, who have trained local communities in Aloe processing techniques, to supply illegal export of large quantities of dried exudate [21,22]. This trade is sustained by the global demand for Aloe products [7]. Another, less specific threat to the aloes is the general loss and destruction of habitats due to increase in human and livestock populations (e.g. [23]). In addition to national protection in Kenya, aloes and their products are regulated in international trade by the Convention on International Trade in Endangered Species (CITES) and are all listed on CITES appendix II [9]. The IUCN Red List [24], furthermore, records only seven species of Aloe in three most threatened categories 'Critically endangered,' 'Endangered' or "Vulnerable". The 25 endemic Aloe species of Kenya were evaluated by Wabuyele et al. [11], who concluded that no fewer than 16 species were either 'Critically endangered' or 'Endangered', according to IUCN Red List criteria. In spite of growing awareness for the threats to Aloe species in Kenya and these attempts to protect them, illegal harvesting is still taking place. Although there is evidence of an ongoing demand for the processed aloe exudate, the (legal) non-commercial uses of Aloe species in rural communities, and the sustainability of local Aloe harvesting, have not been recently assessed.

Kenya's drylands support $28 \%$ of the total human population and occupy $80 \%$ of the land area. Sustainable utilization of Aloe resources in the drylands has been advocated [17] as a step towards empowering the local communities for better livelihoods and, indirectly, biodiversity conservation. Knowledge about the uses of aloes is crucial to help prioritise conservation and research efforts towards the most valued and threatened species. Plant value, in particular, can be a convincing argument for conservation attention, but is difficult to quantify since folk uses and cultural significance are rarely evaluated in economic terms [7]. Grace et al. [4] argued that a variety of indicators can be used to estimate the cultural and economic value of Aloe, such as the number of vernacular names and number of uses recorded for a species. Holman [25] demonstrated that the ways local communities name plants reveals important information about the plants' relative importance to the community. Earlier studies have shown that in South Africa most species of Aloe are used [26], and the same has been reported about aloes in Kenya [16]. In this study, we aimed to assess the contemporary biocultural importance of Aloe species in Kenya, using a case study to examine the uses, vernacular names and sustainability of noncommercial wild harvesting and gather perceptions of population changes among nine ethnic groups in Kenya. Specifically, the aims of this study were to document the vernacular names and local uses of aloes in Kenya, explore the distribution of local knowledge about Aloe species in relation to age and gender, and record people's understanding of changes in abundance and distribution of aloes.

\section{Methods}

\section{Study area}

The study area (Fig. 1a) was selected to areas in Kenya with a minimum of two Aloe taxa present, and areas of very low human population density, like Northern Kenya, were avoided. The study area was further selected to include a wide range of ethnic groups, representing different linguistic groups: Cushitic, Nilotic and Bantu (Fig. 1b). When this fieldwork was undertaken, Kenya comprised eight provinces (Swahilia: mikoa), that were subdivided into 69 districts (wilaya) and 497 divisions (taarafa). Under the new constitution (envisioned by the 2010 Constitution of Kenya), the former subdivisions were abandoned, and Kenya is now divided into 47 counties. Counties where information was collected are highlighted in grey (Fig. 1a), with the old provinces indicated.

The ethnobotanical survey was undertaken during August and September 2005. Information was collected by interviewing 63 respondents from nine ethnic groups (Kamba, Kikuyu, Kisii, Masaii, Mbeere, Taita, Tugen, Samburu, Somali). Informants were selected to represent a broad spectrum of the communities, ages, gender and occupations, from herders to herbalists. The two youngest informants were 18 years old, the oldest estimated her age to around 100 years; the age and gender of informants are presented in Fig. 2. Semi-structured interviews were conducted with each respondent while walking in Aloe localities in the vicinity of the respondents' homes. The information collected included vernacular names of plants, plant uses, 


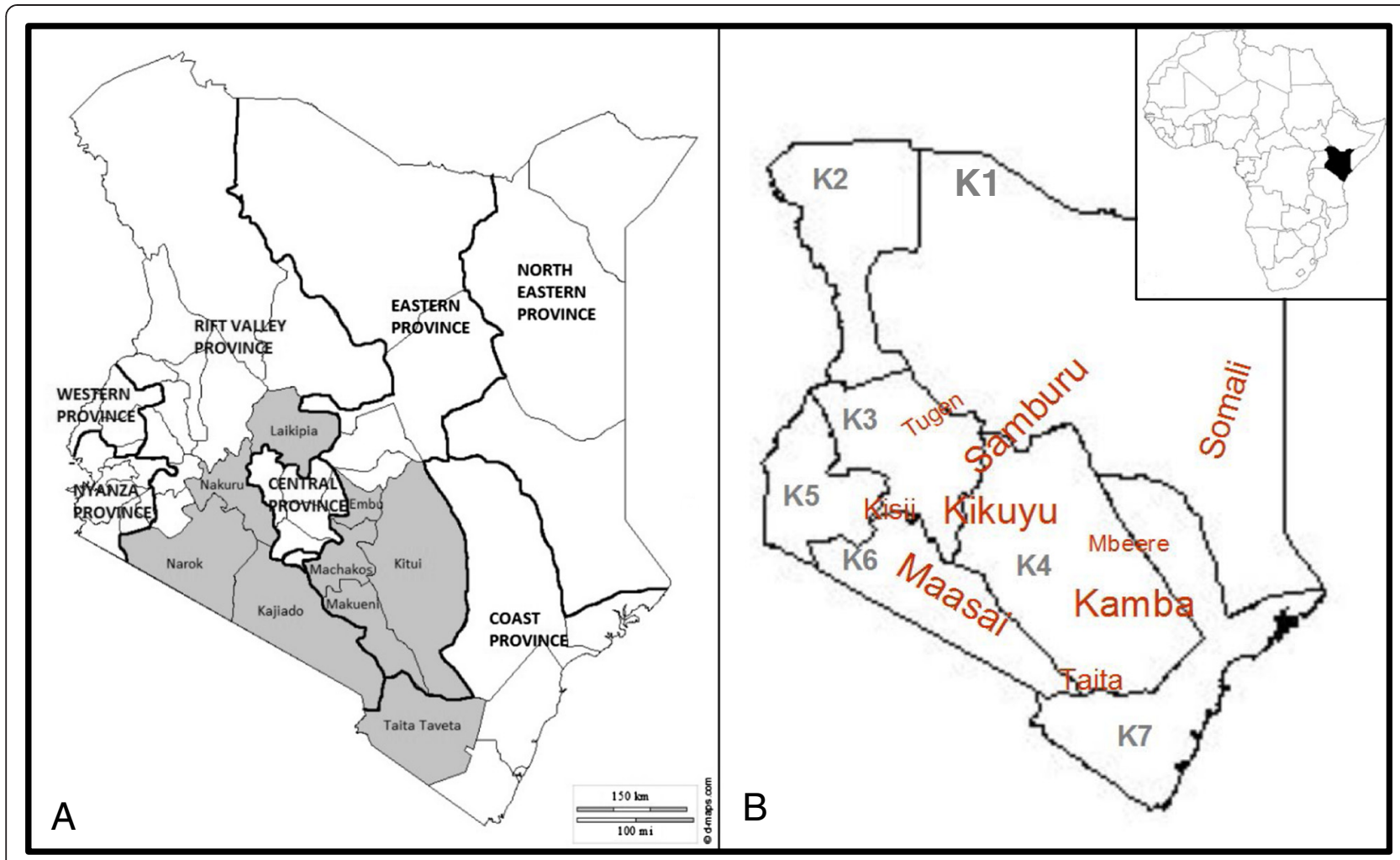

Fig. 1 a. Map of Kenya showing study area (highlighted). b. Flora regions following Flora of Tropical East Africa (FTEA) and ethnic groups represented in the study area. Label size indicates the size of the ethnic group

harvesting procedures and preparation methods, plant population abundance, and whether changes had been registered through time. Where abundance was said to have changed, the informants were asked to suggest reasons for this. To get an indication of the informants' general knowledge of the area, they were asked about issues such as land ownership, uses of other plants and ecological information like flowering times. Finally, the respondents were asked to rank the locally occurring Aloe species according to the single criterion of importance to themselves, reflecting the overall value they placed on different Aloe species.

To organise the information, the unique use records were categorised into the following classes: medicinal (humans), veterinary, fodder, local brew, fencing and soil stabilising, cosmetic, and "other" uses. All unique use records are listed in Appendix 1. Only specific uses were recorded, if respondents reported e.g. "this aloe is used to treat animals against diseases", this was not counted,

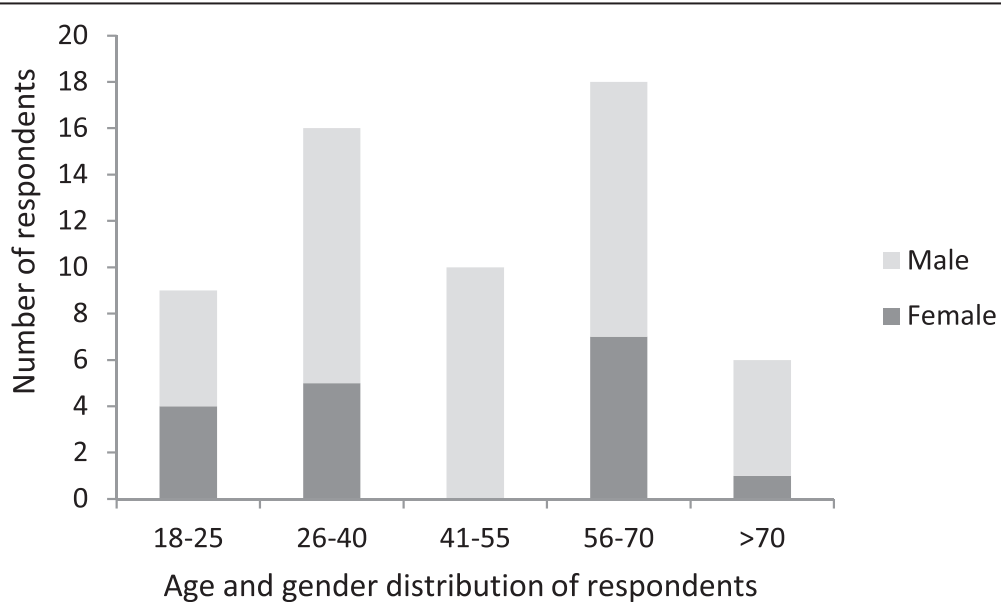

Fig. 2 Distribution of the respondent's age and gender 
as it was too vague to distinguish it from other uses. Vouchers for all species are deposited in East African (EA) and or Oslo herbaria (O).

Information on the distribution and uses of aloes was collated from existing literature e.g. $[6,8,10,12$, 13, 27-32], as well as specimens deposited at the East African Herbarium (EA) and the Herbarium at the Royal Botanic Gardens, Kew (K).

\section{Statistical analyses}

Statistical analyses of the data were performed using $R$ version 3.1.2.for Windows [33]. To test if there was any correlation between the age of the informant and their knowledge of use of aloes (unique use records), the nonparametric Kendall's $\tau$ test was performed. To test if there was a significant difference between the informant's gender and knowledge of use of aloes the non-parametric Wilcoxon-Mann-Whitney $U$-test was performed. These tests were both based on 58 observations. To test if the number of unique use records was correlated with the distribution of the aloe species, a Kendall's $\tau$ test was performed based on 19 observations. To see if there was a connection between number of unique use records and people's perception of decrease in local aloe populations we did a Wilcoxon-Mann-Whitney $U$-test based on 73 observations.

\section{Results}

\section{Names - ethnotaxonomy}

A total of 19 Aloe species were encountered in the study area. Vernacular names are presented in Table 1 with reference to the scientific names. All nine ethnic groups in this study had a name more or less equivalent to the scientific genus name, e.g. "suguroi" (Samburu), osuguroi (Maasai), cheretwo (Tugen), kiluma (Kamba) (Table 1). These names were constant within the ethnic groups over extensive geographical areas. Little or no variation in the names was observed at the generic level, whereas at lower taxonomic levels we observed more variation and less stability in names. Sometimes different names were used for two populations of the same species; this was often linked to morphological variation. For example, if the plants in one population of Aloe secundiflora had spotted leaves in one locality, but not in another, these were often named differently, as kiluma (A. secundiflora, not spotted) and kiluma kila kimaa (A. secundiflora, spotted) in the Kamba language. The first, with no additional name, was often referred to as the "real" kiluma.

When more than one Aloe taxon was identified within an area, a name in addition to the generic name was added (rather like the binomial scientific nomenclature) to describe the taxon it referred to. For instance, among the Samburu, if plants of A. secundiflora, which is stemless or has a very short stem, grows in the vicinity of the tall A. ngongensis Christian, A. ngongensis would be referred to as suguroi lengejonabo (one legged aloe), while $A$. secundiflora would be referred to as suguroi. In other examples, the naming was also linked to use, such as osuguroi lenesho (Maasai), meaning the aloe of beer. Sometimes the same name was used for different scientifically recognized taxa, e.g. suguroi mara, (the spotted aloe) was the name for a spotted $A$. secundiflora in one area, while it was referred to a heavily spotted $A$. laterita Engl. in another area.

\section{Local uses - ethnobotany}

Among the 19 species of Aloe found in the study area, the highest number of unique uses were recorded for $A$. secundiflora (Figs. 3, 4d). All respondents, irrespective of ethnic group, ranked this species as the most important. The informants mentioned twice as many unique uses for this species compared to the second most-used species, A. lateritia.

Altogether, 57 unique uses were mentioned for Aloe secundiflora, of which about $70 \%$ were for medicinal uses in humans and livestock (Appendix 1). This species was also the most popular in most categories of use, except for cosmetic use, where A. lateritia was more frequently cited. Aloes were often mentioned as fodder plants, and Aloe ngongensis was as important as $A$. secundiflora for this purpose. The plants are browsed during drought, when other fodder plants are scarce; this was the case in many localities, over several ethnic groups. The importance of Aloe nyeriensis as a fodder plant among the Samburu and Masai is demonstrated by its vernacular name: aloe of goats (suguroi ngare).

Malaria was the most frequently mentioned ailment that aloes were used to treat. People did not use it uncritically however; being aware it might be lethal taken under certain circumstances (Appendix 1). In the current study $50 \%$ (nine species) were used for this purpose by eight different ethnic groups. The second most mentioned use was for treatments of poultry diseases; seven different ethnic groups used six species for this purpose (Appendix 1).

Besides the similarities in uses recorded for each species of Aloe, some uses were linked to only one or a few ethnic groups, and were not widely shared across the ethnic groups surveyed. One of the most frequent uses, mentioned by informants from the Samburu and Masai ethnic groups, was the use of Aloe secundiflora for making traditional beer. The roots are dug up, stripped, soaked in honey and dried before being processed further for improving fermentation (Fig. 4e).

For 40 of the Aloe species in Kenya we did not find any documentation of use; as many as 22 of these are endemic species only found within a restricted area. 
Table 1 Ethnotaxonomical naming of Aloe species by nine ethnic groups in Kenya

\begin{tabular}{|c|c|c|c|}
\hline Scientific name & Language: (linguistic classification) & Local name(s) & Translation \\
\hline A. aggeodonta & Kamba (B) & kiluma & aloe \\
\hline \multirow[t]{2}{*}{ A. ballyi } & Mberee (B) & kithunju & aloe \\
\hline & Taita (B) & kipapa & aloe \\
\hline A. classenii & Taita (B) & kipapa & aloe \\
\hline A. chrysostachys & Mberee (B) & kithunju & aloe \\
\hline \multirow[t]{2}{*}{ A. deserti } & Kamba (B) & kiluma & \\
\hline & Maasai (N) & (o)suguroi lengejonabo & The one legged aloe \\
\hline A. elata & Maasai (N) & (o)suguroi lengejonabo & The one legged aloe \\
\hline A. fibrosa & Kamba (B) & kiluma & aloe \\
\hline \multirow[t]{6}{*}{ A. kedongensis } & Maasai (N) & (o)suguroi & aloe \\
\hline & & (o)suguroi onyokie & The greyish aloe \\
\hline & & (o)suguroi olongapeta & The aloe of long post \\
\hline & Kikuyu (B) & munywanugu & The aloe eaten by baboons \\
\hline & Kisii (B) & omugaka & aloe \\
\hline & Tugen-Aror (N) & cheretwo & aloe \\
\hline \multirow[t]{12}{*}{ A. lateritia } & Kamba (B) & Kiluma & aloe \\
\hline & & Kiluma kila kimaa & The spotted aloe \\
\hline & Kikuyu (B) & Kil(/r)uma & aloe \\
\hline & Kisii (B) & Omugaka & aloe \\
\hline & Maasai (N) & (o)suguroi & aloe \\
\hline & Samburu (N) & suguroi lekoshe & aloe \\
\hline & & suguroi mara & The spotted aloe \\
\hline & & suguroi sambu & The spotted aloe \\
\hline & Somali (C) & warabe & aloe \\
\hline & Taita (B) & kipapa & aloe \\
\hline & Tugen (N) & tangaratweti & aloe \\
\hline & Tugen-Aror (N) & cheretwo & aloe \\
\hline \multirow[t]{2}{*}{ A. morijensis } & Maasai (N) & (o)suguroi & aloe \\
\hline & & (o)suguroi lekpo & The aloe of down \\
\hline A. murina & Maasai (N) & (o)suguroi & aloe \\
\hline \multirow[t]{2}{*}{ A. ngongensis } & Samburu (N) & suguroi & aloe \\
\hline & & suguroi lengejonabo & The one legged aloe \\
\hline \multirow[t]{2}{*}{ A. ngongensis (cont.) } & & suguroi keri & The purple/ greyish aloe \\
\hline & Taita (B) & kipapa & aloe \\
\hline \multirow[t]{3}{*}{ A. nyeriensis } & Samburu (N) & suguroi lodo/yodo & The tall aloe \\
\hline & & suguroi mara & The spotted aloe \\
\hline & & suguroi ngare & The aloe of goats \\
\hline A. penduliflora & Taita (B) & kipapa & aloe \\
\hline A. scabrifolia & Samburu (N) & suguroi & aloe \\
\hline \multirow[t]{5}{*}{ A. secundiflora } & Kikuyu (B) & Kil(/r)uma & aloe \\
\hline & Maasai (N) & (o)suguroi & aloe \\
\hline & & (o)suguroi kianwan & The real aloe \\
\hline & & (o)suguroi kirimo & The spotted aloe \\
\hline & & (o)suguroi lengiok & The large leaved aloe \\
\hline
\end{tabular}


Table 1 Ethnotaxonomical naming of Aloe species by nine ethnic groups in Kenya (Continued)

\begin{tabular}{|c|c|c|c|}
\hline & & (o)suguroi lenesho/lenaisho & aloe of beer \\
\hline & & (o)suguroi lenkejunabo & The one legged aloe \\
\hline & & (o)suguroi onyori & The green aloe \\
\hline & & (o)suguroi orok & The short aloe \\
\hline & & Inkoisikirianchoi & aloe \\
\hline & Mbeere (B) & githunju/kithunju & aloe \\
\hline & Samburu (N) & suguroi & aloe \\
\hline & & suguroi mara & The spotted aloe \\
\hline & & suguroi orok/yorok & The black aloe \\
\hline & Somali (C) & dahr & aloe \\
\hline & Taita (B) & kipapa & aloe \\
\hline & Tugen-Aror (N) & cheretwo & aloe \\
\hline \multirow[t]{2}{*}{ A. ukambensis } & Kamba (B) & kiluma & aloe \\
\hline & & kiluma kya ivia & The aloe of the rock \\
\hline A. vituensis & Samburu (N) & no name & \\
\hline \multirow[t]{2}{*}{ A. volkensii } & Maasai (N) & (o)suguroi & aloe \\
\hline & & (o)suguroi lombokishi & The aloe of long post \\
\hline
\end{tabular}

Species in bold are endemic to Kenya. Linguistic classifications C Cushitic, $N$ Nilotic and $B$ Bantu

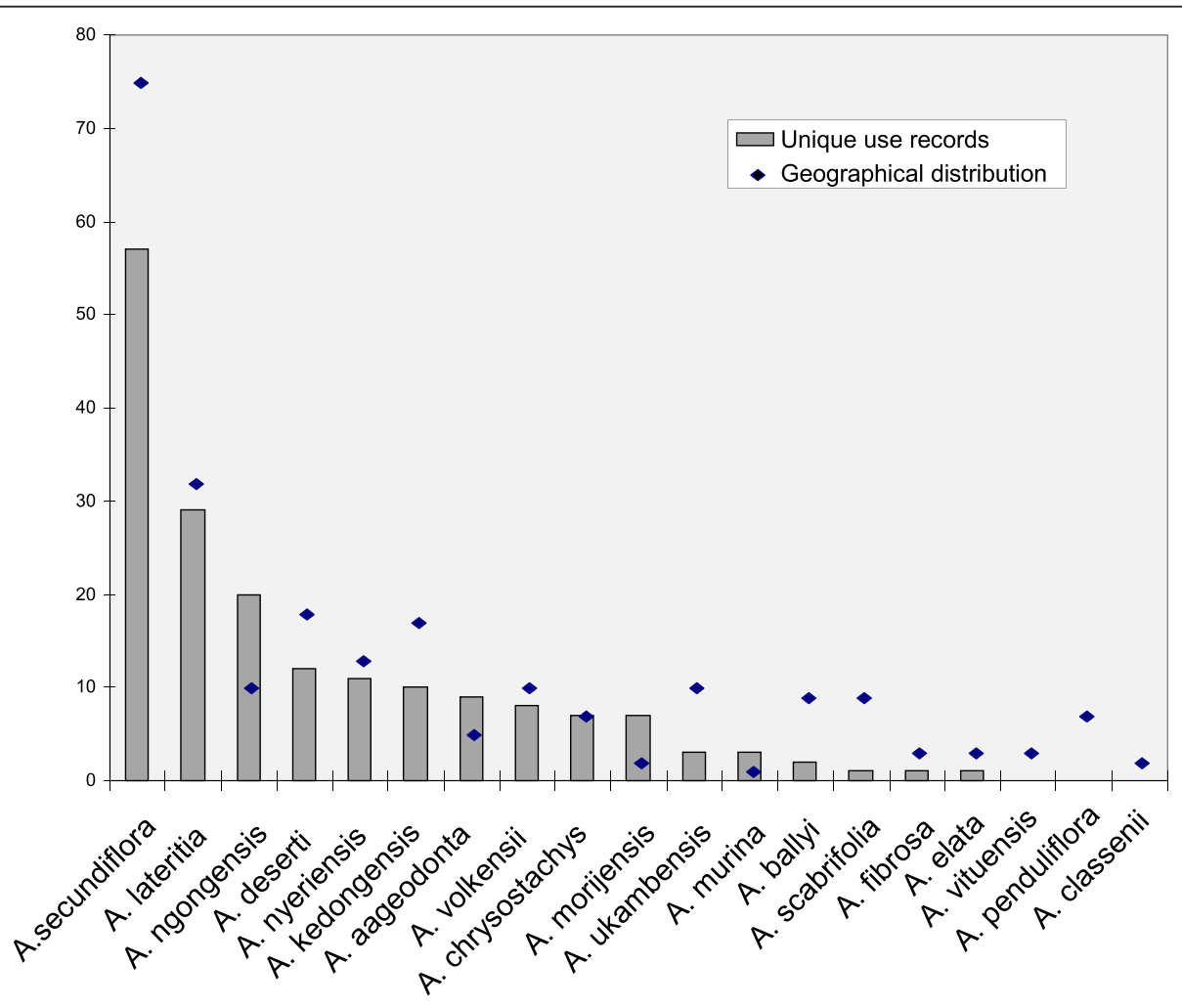

Fig. 3 Number of unique uses for each Aloe species in the study area and geographical range represented by the number of recorded localities for the species from the East African-, Kew- and Oslo-herbaria 

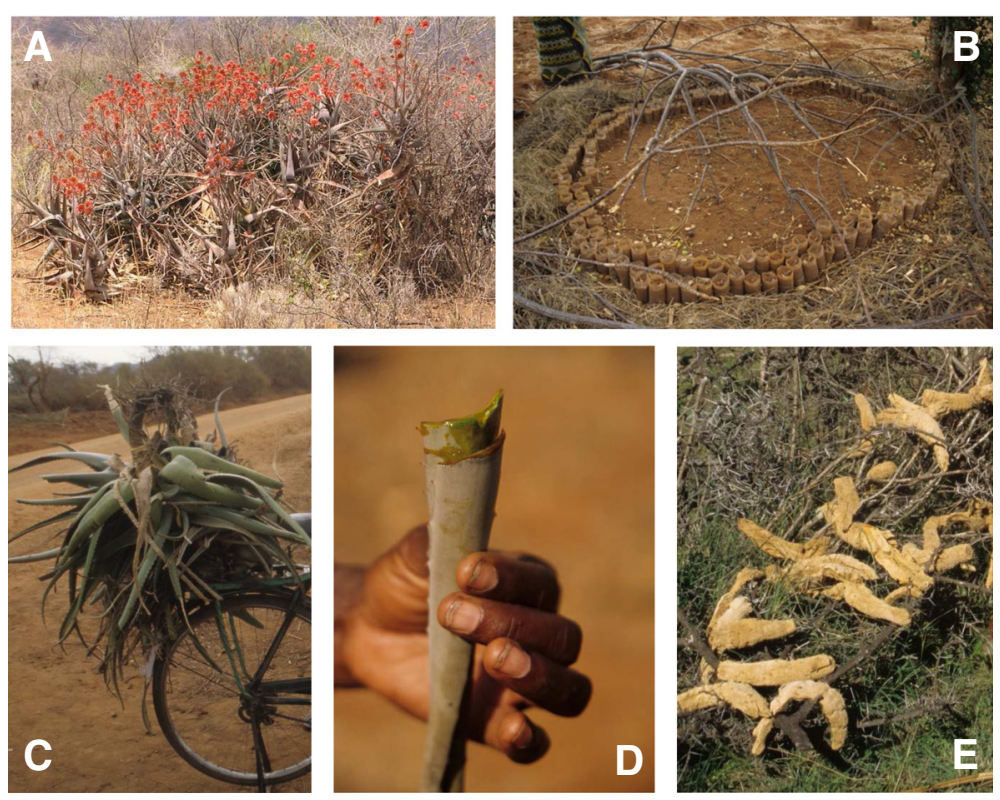

Fig. 4 a Aloe kedongensis bearing the local name "suguroi onyokie" -the grey aloe. b Local propagation of Aloe secundiflora: seedlings are fenced to avoid browsing. c Collection of wild Aloe secundiflora for cultivation. $\mathbf{d}$ Aloe secundiflora is the most commonly used Aloe in Kenya. e Aloe secundiflora roots stripped and dried to be used in local beer production, and thus named "suguroi lenesho" - aloe of beer

Species such as Aloe amicorum L.E.Newton and A. kulalensis L.E.Newton \& Beentje are found in remote areas almost inaccessible to people or at great distances from where people live. Their geographical isolation is a likely reason for the lack of documented uses.

\section{Distribution of knowledge}

In this study, no significance in the level of knowledge between older and younger people was found $(\tau=0.0727, P=0.4380)$, nor were there any significant differences between the genders $(\mathrm{W}=364.5, \mathrm{P}=0.7906)$. The Maasai and Kamba ethnic groups listed highest numbers unique use records for the Aloe species (Appendix 1).

\section{Popular perception of change in aloe abundance}

Older respondents were more likely to report perceptible decreases in Aloe availability and abundance than younger respondents. However, no correlation was found between species with a high number of unique use records and those with a perceived decline in population size $(\mathrm{W}=587, \mathrm{P}=0.6230)$. On the contrary, in some cases, high levels of use tended to increase the local abundance and availability of a species since people actively cultivated the plants (Fig. 4). In the Taita Hills, one of the informants had a nursery for Aloe secundiflora for use in the commercial production of soap (Fig. 4b). When collecting ethnobotanical data during this study, several historic Aloe localities (including type localities) were visited. However many species were not found, often due to habitat destruction and the loss of the locality, supporting mounting concerns [11] for the conservation of Aloe in Kenya.

\section{Discussion}

Aloes are easily distinguished from other plants by their characteristic succulent spiny leaves, and thus it is not surprising that the local naming at the genus level is consistent with the scientific species concepts. However, a species may be given two names to reflect the appearance or use of the plants. When two species have the same vernacular name, they also share the way of use, and the local people therefore have no practical need to distinguish the species.

The vernacular names of Aloe species in Kenya are closely linked to use. In all areas where the widespread and widely used $A$. secundiflora occurred, this species was referred to as "the aloe" or "the real aloe". In our study region, relatively few species of Aloe co-occur, making the recognition of Aloe secundiflora sufficient to distinguish the other species from "the real one" by descriptive characteristics like "the tall aloe" or "the grey aloe". This naming also reflects the importance of the different species to the local communities; the "real aloe" is the most important aloe, and the other species are less important. If an aloe is not of any specific use, it is often not given any name at all. When the respondents were asked for names of some these species, they responded: "it is an aloe, but not a real one". Our observations of 
vernacular nomenclature applied to Aloe spp. and overlap with scientific species concepts agree broadly with previous studies that have reported a binomial system in which vernacular names describe the plant name and its use [34, 35].

Aloe secundiflora and A. lateritia were the most important Aloe species in our study area according to the respondents, and this is evident in the wide variety of uses listed for these species. Several informants said, when describing the uses of Aloe lateritia, that it was used when $A$. secundiflora was not available. They further claimed that the Aloe lateritia is not as bitter as $A$. secundiflora, and hence not as effective. These two species are the most widespread in our study area, and thus have the greater potential of being used compared to other more geographically restricted species (Fig. 3). The different traditions of the nine ethnic groups surveyed contributed to increasing the diversity of uses recorded for these widespread species. Aloe secundiflora and A. lateritia are the only species of Aloe that are found in almost all of the seven Flora regions (Flora of Tropical East Africa K1- K7 Fig. 1b, [8]). Most aloes in Kenya are geographically restricted, but might at the same time be locally common $[8,11]$. This is the case for species like Aloe aageodonta L.E.Newton and A. chrysostachys Lavranos \& L.E.Newton, which are found only in the Flora region K4. The respondents used these species in more or less the same way as Aloe secundiflora in other areas. But where the two species (Aloe secundiflora and A. lateritia) were readily available, these were mostly preferred. Interestingly, other ethnobotanical studies elsewhere in Kenya and Uganda reported that the use of mixtures of medicinal plants, including Aloe spp., is much less common than the use of single-species preparations [35-37]. Poisonous members of the genus, like Aloe ballyi Reynolds and also A. elata S.Carter \& L.E.Newton, which are used by people for arrow poison, are known to contain toxic hemlock alkaloid $\gamma$-coniceine [29], are generally avoided by humans and cattle.

Two uses were emphasized by respondents in each of the nine ethnic groups: the use of Aloe species for the treatment of malaria and for poultry diseases. These findings are supported by pharmacological studies e.g. $[30,31]$ and ethnobotanical studies in Kenya that have reported malaria as the greatest medical concern treated with herbal remedies e.g. [35]. Similarly, aloes feature prominently in ethnoveterinary medicine throughout their range and are most valued for their uses against insect pests [26, 34, 36]. The relative importance of Aloe in ethnomedicine and ethnoveterinary medicine should be understood in the regional context; in some areas of East Africa, herbal treatments are the only option for up to $80 \%$ of the population [14].
Our data suggest that knowledge about the uses of Aloe species is commonly held among community members in Kenya, and knowledge is distributed evenly across ages and gender. That the Maasai and Kamba ethnic groups listed the highest numbers unique use records, might only be a reflection of the relative higher species diversity within their residential areas. Aloes are renowned internationally and some of the formally educated respondents claimed that the name of the local aloe (most often A. secundiflora) was $A$. vera, and that it was indigenous to Kenya. Public opinion about $A$. vera as "a wonder drug" has therefore been transferred to local aloes. In contrast to a general belief that all aloes are used wherever they grow [16] we could not find any documentation of use for $63 \%$ of the Kenyan aloes (Fig. 5). The extent to which a species is uses is a result of the combination of availability and suitability for a particular purpose. Widespread species of Aloe are generally more frequently used than geographically restricted species, and uses are influenced by the growth form of the aloes. The shrubby $A$. ngongensis, A. kedongensis Reynolds and A. nyeriensis and the small tree $A$. volkensii Engl. are more suitable for fencing and hedging than the smaller and acaulescent species.

Species that are only found at one or few remote localities appear to be overlooked because people do not have easy access to the plants. However, some species that are relatively accessible are not used. Three $(A$. classenii Reynolds, A. penduliflora Baker and A. vituensis Baker) out of a total of 19 species documented in this study had no reported use. A few species had very limited use, such as A. fibrosa Lavranos \& L.E.Newton and A. elata, for which the only reported use was as ornamentals. One special case is the very widespread A. myriacantha (Haw.) Schult. \& Schult. f. (Fig. 5). Being a "grass aloe" it lacks the typical succulent leaves that people use. Succulent leaves have been positively correlated with the likelihood that an Aloe species is used for medicine [38]. Dying back in the dry season, people probably do not regard this as an aloe at all.

Local knowledge of natural resources has been recognised as an important element of effective conservation strategies in Kenya [37]. We found no significant connection between high numbers of recorded uses and perceived decreases in Aloe population sizes. Harvesting practices differ markedly in their impact on the Aloe plant: only small pieces of the leaves are used for the various medical uses while, in contrast, the whole plant is dug up when the stems are used for making beer, or the entire plant for fodder. However, we found no correlation between decrease in aloe populations and either the tradition of beer- 


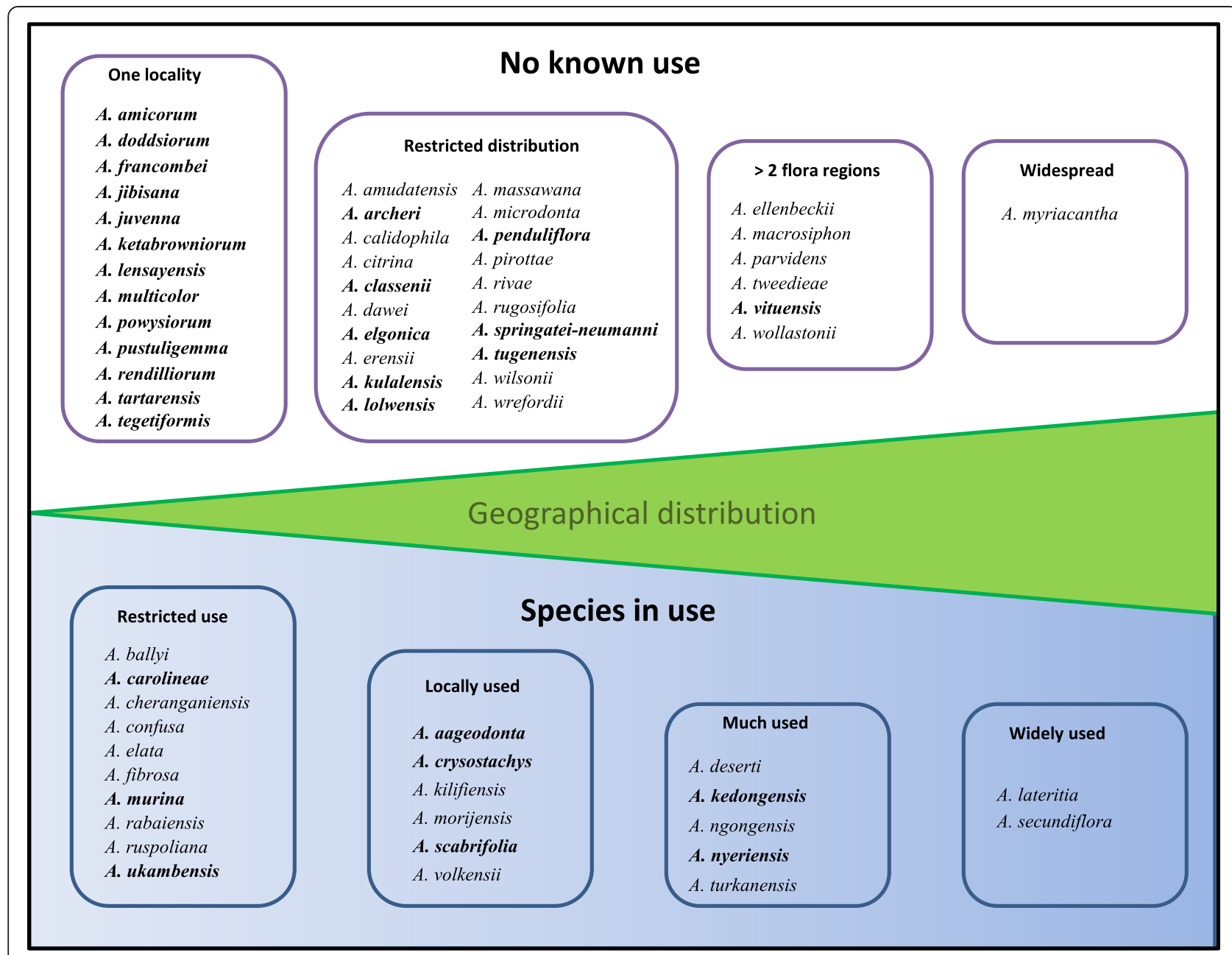

Fig. 5 Extent of use and distribution of all Kenyan Aloe species; endemic species are indicated in bold. Based on own study, literature and herbarium records

making or the use aloes for fodder. This might indicate that local harvesting in general is done on a sustainable basis, and that habitat destruction due to increase in human and livestock populations poses a more urgent threat to Aloe species Kenya. Indeed, changes in land use were the most frequently given reasons for perceived declines in Aloe populations. Another factor that could be influential is that the most used species Aloe secundiflora is very common: a survey done by Mukonyi et al. (Mukonyi KW, Situma CA, Lusweti A, and Kyalo, S. Sustainable utilization of commercial Aloe resources in the drylands of Kenya 2005. Unpublished report) estimated the Kenyan population of commercial aloes at 129 million plants, $83 \%$ of which were $A$. secundiflora. With such an abundant species, declining availability should be quickly noticeable. However, several respondents reported that they have to walk longer distances than before to collect their medicine from an Aloe population. As a consequence, aloes are more frequently planted in residential compounds to ensure the plants are accessible when they are needed (Fig. 4c). Local people are actively propagating seeds and replanting plantlets from other populations, conserving the local genetic diversity of Aloe species. Further, several informants responded that when moving from another area they had brought the aloes with them, indicating that the most-used aloes also are spread by humans. The succulent leaves allow aloes to survive for a long time out of soil, and the practice of moving aloes is well known [16]. Aloe vera, in particular, is an example with highly expanded distribution due to use, and was spread from the Arabian Peninsula along the trade routes to the Mediterranean, India, Americas and Caribbean [1,38].

There is a close connection between the diversity of use and geographical distribution of Aloe species in Kenya (Figs. 3, 5). Not surprisingly, the wider the distribution range is for a species, the higher the number 


\section{Appendix}

Table 2 The unique uses of Aloes in the study area with reference to ethnic group. The uses are categorized into seven groups of use. Species are presented sequential from the most to the least used. K-Kamba, Ki-Kikuyu, Kii-Kisii, Ma-Maasai, Mb-Mbeere, Sa-Samburu, So-Somali, T- Taita, Tu- Tugen

\begin{tabular}{|c|c|c|c|c|c|c|c|c|c|}
\hline Medicinal, humans & $\begin{array}{l}\text { Ethnic } \\
\text { group }\end{array}$ & $\begin{array}{l}\text { Medicinal, } \\
\text { livestock }\end{array}$ & $\begin{array}{l}\text { Ethnic } \\
\text { group }\end{array}$ & Fodder & $\begin{array}{l}\text { Ethnic } \\
\text { group }\end{array}$ & $\begin{array}{l}\text { Fencing, soil } \\
\text { conservation }\end{array}$ & $\begin{array}{l}\text { Ethnic } \\
\text { group }\end{array}$ & $\begin{array}{l}\text { Local } \\
\text { brew }\end{array}$ & $\begin{array}{l}\text { Eth } \\
\text { gro }\end{array}$ \\
\hline \multicolumn{10}{|c|}{ A. aageodonta L.E.Newton } \\
\hline High blood pressure & K & chicken coughs & K & & & & & & \\
\hline Syphilis & K & & & & & & & & \\
\hline Gonorrhoea & K & & & & & & & & \\
\hline Malaria & K & & & & & & & & \\
\hline Diaphragm & K & & & & & & & & \\
\hline \multicolumn{10}{|l|}{ A. ballyi Reynolds } \\
\hline \multicolumn{10}{|c|}{ A. chrysostachys Lavranos \& L.E.Newton } \\
\hline Malaria & $\mathrm{Mb}$ & $\begin{array}{l}\text { Cattle wounds, } \\
\text { fly repellent }\end{array}$ & $\mathrm{Mb}$ & & & Boundaries & $\mathrm{Mb}$ & $\begin{array}{l}\text { Miti } \\
\text { dawa }\end{array}$ & $\mathrm{Mb}$ \\
\hline Pneumonia & K & Chicken cough & K & & & & & & \\
\hline Diaphram & K & & & & & & & & \\
\hline \multicolumn{10}{|l|}{ A. deserti A. Berger } \\
\hline Arthritis & Ma & chicken cough & K & & & & & & \\
\hline Chest pain & K & $\begin{array}{l}\text { chicken } \\
\text { diarrhoea }\end{array}$ & K & & & & & & \\
\hline Gonorrhoea & Ma & $\begin{array}{l}\text { chicken, bile } \\
\text { treatment }\end{array}$ & T & & & & & & \\
\hline Malaria & K & $\begin{array}{l}\text { goats, general } \\
\text { treatment }\end{array}$ & K & & & & & & \\
\hline Pneumonia & Ma & & & & & & & & \\
\hline Retarded growth & Ma & & & & & & & & \\
\hline Tongue, inflammation & $\mathrm{T}$ & & & & & & & & \\
\hline A. elata S.Carter \& L.E.Ne & & & & & & & & & \\
\hline
\end{tabular}

poisonous

A. fibrosa Lavranos \& L.E.Newton 
Table 2 The unique uses of Aloes in the study area with reference to ethnic group. The uses are categorized into seven groups of use. Species are presented sequential from the most to the least used. K-Kamba, Ki-Kikuyu, Kii-Kisii, Ma-Maasai, Mb-Mbeere, Sa-Samburu, So-Somali, T- Taita, Tu- Tugen (Continued)

\begin{tabular}{|c|c|c|c|c|c|c|c|c|c|c|c|c|c|}
\hline Typhoid & Ma & & & $\begin{array}{l}\text { browsed by goats } \\
\text { during drought }\end{array}$ & Ma & $\begin{array}{l}\text { fences, } \\
\text { hedging }\end{array}$ & $\begin{array}{l}\mathrm{Ma} \\
\mathrm{Ka}\end{array}$ & $\begin{array}{l}\text { Miti } \\
\text { dawa }\end{array}$ & Ma & & & ornamental & Ma \\
\hline $\begin{array}{l}\text { Sexually transmitted } \\
\text { diseases }\end{array}$ & $\mathrm{Ma}$ & & & & & & & & & & & $\begin{array}{l}\text { decoration of } \\
\text { sisal basket }\end{array}$ & $\mathrm{Tu}$ \\
\hline Malaria & $\mathrm{Ma}, \mathrm{Ka}, \mathrm{Ki}$ & & & & & & & & & & & & \\
\hline Vomiting & $\mathrm{Ma}$ & & & & & & & & & & & & \\
\hline Diarrhoea & Ma & & & & & & & & & & & & \\
\hline \multicolumn{14}{|l|}{ A. lateritia Engl. } \\
\hline Burns & $\mathrm{Tu}$ & $\begin{array}{l}\text { Chicken } \\
\text { diseases }\end{array}$ & $\mathrm{K}, \mathrm{T}, \mathrm{Tu}$ & $\begin{array}{l}\text { Browsed by goats } \\
\text { (/during drought) }\end{array}$ & Sa & $\begin{array}{l}\text { Demarcating } \\
\text { boundaries }\end{array}$ & Sa & Beer & $\begin{array}{l}\mathrm{Ka}, \mathrm{Ma}, \\
\mathrm{Sa}\end{array}$ & $\begin{array}{l}\text { Hair } \\
\text { treatment }\end{array}$ & Sa & $\begin{array}{l}\text { Not supposed } \\
\text { to touch }\end{array}$ & Kii \\
\hline Coughs & Ma & $\begin{array}{l}\text { Chicken anti } \\
\text { bodies }\end{array}$ & Kii & $\begin{array}{l}\text { Browsed by } \\
\text { sheep }\end{array}$ & Ma & & & & & $\begin{array}{l}\text { Oil- } \\
\text { glycerine }\end{array}$ & Sa & $\begin{array}{l}\text { Attracts } \\
\text { lightening }\end{array}$ & Kii \\
\hline Diarrhoea & $\mathrm{Tu}$ & Goats diarrhoea & K & & & & & & & $\begin{array}{l}\text { Skin } \\
\text { lotion }\end{array}$ & Kii & Bed wetting & $\mathrm{Tu}$ \\
\hline Eye infection & Sa & Sheep diarrhoea & K & & & & & & & pimples & Sa & Frost bite & Sa \\
\hline Eye, allergy & $\mathrm{Ki}$ & & & & & & & & & & & & \\
\hline Eye, used when poison enters & Sa & & & & & & & & & & & & \\
\hline Malaria & $\mathrm{T}$ & & & & & & & & & & & & \\
\hline Pneumonia & $\mathrm{Ma}$ & & & & & & & & & & & & \\
\hline Ringworm & $\mathrm{Ki}, \mathrm{Kii}, \mathrm{Sa}$ & & & & & & & & & & & & \\
\hline Skin disorders & K, Kii, Tu & & & & & & & & & & & & \\
\hline Sleeping sickness & $\mathrm{Tu}$ & & & & & & & & & & & & \\
\hline Stomach ache & $\mathrm{Ki}$ & & & & & & & & & & & & \\
\hline Typhoid & Ma & & & & & & & & & & & & \\
\hline \multicolumn{14}{|l|}{ A. morijensis S.Carter \& Brandham } \\
\hline Pneumonia & $\mathrm{Ma}$ & & & Browsed by goats & $\mathrm{Ma}$ & & & & & & & & \\
\hline Ear alignment & Ma & & & $\begin{array}{l}\text { browsed by } \\
\text { sheep }\end{array}$ & Ma & & & & & & & & \\
\hline Medicinal, humans & $\begin{array}{l}\text { Ethnic } \\
\text { group }\end{array}$ & $\begin{array}{l}\text { Medicinal, } \\
\text { livestock }\end{array}$ & $\begin{array}{l}\text { Ethnic } \\
\text { group }\end{array}$ & Fodder & $\begin{array}{l}\text { Ethnic } \\
\text { group }\end{array}$ & $\begin{array}{l}\text { Fencing, soil } \\
\text { conservation }\end{array}$ & $\begin{array}{l}\text { Ethnic } \\
\text { group }\end{array}$ & $\begin{array}{l}\text { Local } \\
\text { brew }\end{array}$ & $\begin{array}{l}\text { Ethnic } \\
\text { group }\end{array}$ & Cosmetic & $\begin{array}{l}\text { Ethnic } \\
\text { group }\end{array}$ & Other & $\begin{array}{l}\text { Ethnic } \\
\text { group }\end{array}$ \\
\hline \multicolumn{14}{|l|}{ A. morijensis (cont.) } \\
\hline Skin itchy & Ma & & & & & & & & & & & & \\
\hline Vomiting & $\mathrm{Ma}$ & & & & & & & & & & & & \\
\hline Malaria & Ma & & & & & & & & & & & & \\
\hline
\end{tabular}


Table 2 The unique uses of Aloes in the study area with reference to ethnic group. The uses are categorized into seven groups of use. Species are presented sequential from the most to the least used. K-Kamba, Ki-Kikuyu, Kii-Kisii, Ma-Maasai, Mb-Mbeere, Sa-Samburu, So-Somali, T- Taita, Tu- Tugen (Continued)

\begin{tabular}{|c|c|c|c|c|c|c|c|c|c|c|c|c|c|}
\hline \multicolumn{14}{|c|}{ A. ngongensis Christian } \\
\hline Back ache & Ma & & & Browsed by goats & $\mathrm{Ma}$ & Boundaries & Ma & Beer & $\mathrm{Ma}$ & & & & \\
\hline Burns & Ma & & & $\begin{array}{l}\text { Browsed by } \\
\text { sheep }\end{array}$ & $\mathrm{Ma}$ & $\begin{array}{l}\text { Fences, } \\
\text { hedging }\end{array}$ & Ma & & & & & & \\
\hline Diarrhoea & Ma & & & $\begin{array}{l}\text { Browsed by } \\
\text { camels }\end{array}$ & $\mathrm{Ma}$ & & & & & & & & \\
\hline Ear alignment & Ma & & & & & & & & & & & & \\
\hline Gonorrhoea & Ma & & & & & & & & & & & & \\
\hline Itchy skin & Ma & & & & & & & & & & & & \\
\hline Malaria & $\mathrm{Ma}$ & & & & & & & & & & & & \\
\hline Pneumonia & Ma & & & & & & & & & & & & \\
\hline Skin disorders & $\mathrm{K}, \mathrm{Ma}$ & & & & & & & & & & & & \\
\hline Stomach ache & $\mathrm{Ma}$ & & & & & & & & & & & & \\
\hline Syphilis & $\mathrm{Ma}$ & & & & & & & & & & & & \\
\hline Ulcer & $\mathrm{Ma}$ & & & & & & & & & & & & \\
\hline Vomiting & $\mathrm{Ma}$ & & & & & & & & & & & & \\
\hline Wounds & Ma & & & & & & & & & & & & \\
\hline \multicolumn{14}{|c|}{ A. nyeriensis Christian in Verd. } \\
\hline Back ache & $\mathrm{Sa}$ & $\begin{array}{l}\text { Goats diseases, } \\
\text { general }\end{array}$ & $\mathrm{Sa}$ & $\begin{array}{l}\text { Browsed by } \\
\text { camels }\end{array}$ & Sa & $\begin{array}{l}\text { Fences, } \\
\text { hedges }\end{array}$ & Sa & & & & & & \\
\hline Chest pain & Sa & & & Browsed by goats & Sa & & & & & & & & \\
\hline Clean blood & Sa & & & & & & & & & & & & \\
\hline Eye infection & Sa & & & & & & & & & & & & \\
\hline Gonorrhoea & Sa & & & & & & & & & & & & \\
\hline Release bladder & Sa & & & & & & & & & & & & \\
\hline Wounds & Sa & & & & & & & & & & & & \\
\hline Medicinal, humans & $\begin{array}{l}\text { Ethnic } \\
\text { group }\end{array}$ & $\begin{array}{l}\text { Medicinal, } \\
\text { livestock }\end{array}$ & $\begin{array}{l}\text { Ethnic } \\
\text { group }\end{array}$ & Fodder & $\begin{array}{l}\text { Ethnic } \\
\text { group }\end{array}$ & $\begin{array}{l}\text { Fencing, soil } \\
\text { conservation }\end{array}$ & $\begin{array}{l}\text { Ethnic } \\
\text { group }\end{array}$ & $\begin{array}{l}\text { Local } \\
\text { brew }\end{array}$ & $\begin{array}{l}\text { Ethnic } \\
\text { group }\end{array}$ & Cosmetic & $\begin{array}{l}\text { Ethnic } \\
\text { group }\end{array}$ & Other & $\begin{array}{l}\text { Ethnic } \\
\text { group }\end{array}$ \\
\hline \multicolumn{14}{|c|}{ A. scabrifolia L.E.Newton \& Lavranos } \\
\hline & & & & & & & & & & & & Gums for arrows & Ma \\
\hline \multicolumn{14}{|l|}{ A. secundiflora Engl. } \\
\hline Arthritis & $\mathrm{Ma}$ & $\begin{array}{l}\text { Cattle disease, } \\
\text { general }\end{array}$ & Sa & $\begin{array}{l}\text { Goats browsing } \\
\text { bark }\end{array}$ & $\mathrm{Ma}$ & Boundaries & Ma & Beer & $\mathrm{Ma}, \mathrm{Sa}$ & $\begin{array}{l}\text { Skin } \\
\text { lotion }\end{array}$ & So & $\begin{array}{l}\text { Goats die with } \\
\text { eating }\end{array}$ & Sa \\
\hline
\end{tabular}


Table 2 The unique uses of Aloes in the study area with reference to ethnic group. The uses are categorized into seven groups of use. Species are presented sequential from the most to the least used. K-Kamba, Ki-Kikuyu, Kii-Kisii, Ma-Maasai, Mb-Mbeere, Sa-Samburu, So-Somali, T- Taita, Tu- Tugen (Continued)

\begin{tabular}{|c|c|c|c|c|c|c|c|c|c|c|c|c|c|}
\hline Backache & Ma & $\begin{array}{l}\text { Cattle wounds, } \\
\text { fly repellent }\end{array}$ & $\mathrm{Mb}$ & $\begin{array}{l}\text { Eaten by livestock } \\
\text { during drought }\end{array}$ & Sa, So & $\begin{array}{l}\text { Demarcating } \\
\text { roads }\end{array}$ & Ma & $\begin{array}{l}\text { Miti } \\
\text { dawa }\end{array}$ & $\mathrm{T}$ & Soap & T & $\begin{array}{l}\text { Inflorescence eaten by } \\
\text { children }\end{array}$ & Ma \\
\hline Bile problems & Ma & $\begin{array}{l}\text { Cattle, eye } \\
\text { infection }\end{array}$ & Sa, So & & & $\begin{array}{l}\text { Fences, } \\
\text { hedging }\end{array}$ & Ma & & & & & $\begin{array}{l}\text { Killing brown } \\
\text { ticks }\end{array}$ & $\mathrm{Tu}$ \\
\hline Burns & Ma, So & Chicken cough & $\begin{array}{l}\mathrm{K}, \mathrm{Mb}, \\
\mathrm{T}\end{array}$ & & & Soil erosion & Ma & & & & & Ornamental & $\begin{array}{l}\mathrm{K}, \mathrm{Ma}, \\
\mathrm{T}\end{array}$ \\
\hline $\begin{array}{l}\text { Cold, flue, coughs, } \\
\text { Chest problems }\end{array}$ & $\begin{array}{l}\text { K, Ma, Sa, } \\
\text { So }\end{array}$ & $\begin{array}{l}\text { Chicken white } \\
\text { droppings/ } \\
\text { diarrhoea }\end{array}$ & K, So & & & & & & & & & $\begin{array}{l}\text { Poison for } \\
\text { arrows }\end{array}$ & K \\
\hline Diabetes & So & $\begin{array}{l}\text { Chicken, remove } \\
\text { mite }\end{array}$ & K & & & & & & & & & Ritual & Ma \\
\hline Diarrhoea, induce & $\mathrm{Ma}, \mathrm{T}$ & Goats diarrhoea & $\begin{array}{l}\mathrm{K}, \mathrm{Ma} \\
\mathrm{Sa}, \mathrm{So}\end{array}$ & & & & & & & & & & \\
\hline Diarrhoea, stopping of & Ma & $\begin{array}{l}\text { Goat disease, } \\
\text { general }\end{array}$ & K & & & & & & & & & & \\
\hline $\begin{array}{l}\text { Eye infection, Trachoma } \\
\text { conjunctivitis }\end{array}$ & $\mathrm{Ma}$, Sa & $\begin{array}{l}\text { Sheep's } \\
\text { diarrhoea }\end{array}$ & K & & & & & & & & & & \\
\hline Gonorrhoea & $\mathrm{Ma}$ & & & & & & & & & & & & \\
\hline Headache & Ma & & & & & & & & & & & & \\
\hline High blood pressure & So & & & & & & & & & & & & \\
\hline Infections, cleaning of & Sa & & & & & & & & & & & & \\
\hline Itchy skin & So & & & & & & & & & & & & \\
\hline Kidney problems & Ma & & & & & & & & & & & & \\
\hline Liver problems & K & & & & & & & & & & & & \\
\hline Malaria & $\begin{array}{l}\mathrm{K}, \mathrm{Ma}, \mathrm{Mb} \\
\text { Sa, So, T, Tu }\end{array}$ & & & & & & & & & & & & \\
\hline Medicinal, humans & $\begin{array}{l}\text { Ethnic } \\
\text { group }\end{array}$ & $\begin{array}{l}\text { Medicinal, } \\
\text { livestock }\end{array}$ & $\begin{array}{l}\text { Ethnic } \\
\text { group }\end{array}$ & Fodder & $\begin{array}{l}\text { Ethnic } \\
\text { group }\end{array}$ & $\begin{array}{l}\text { Fencing, soil } \\
\text { conservation }\end{array}$ & $\begin{array}{l}\text { Ethnic } \\
\text { group }\end{array}$ & $\begin{array}{l}\text { Local } \\
\text { brew }\end{array}$ & $\begin{array}{l}\text { Ethnic } \\
\text { group }\end{array}$ & Cosmetic & $\begin{array}{l}\text { Ethnic } \\
\text { group }\end{array}$ & Other & $\begin{array}{l}\text { Ethnic } \\
\text { group }\end{array}$ \\
\hline \multicolumn{14}{|l|}{ A. secundifloracont. } \\
\hline Oral thrush & $\mathrm{Tu}$ & & & & & & & & & & & & \\
\hline Pain relief & K & & & & & & & & & & & & \\
\hline Pancreas, swelling of & K & & & & & & & & & & & & \\
\hline Peptic ulcer & K & & & & & & & & & & & & \\
\hline Pneumonia & $\begin{array}{l}\mathrm{K}, \mathrm{Mb}, \mathrm{Sa} \text {, } \\
\mathrm{Tu}\end{array}$ & & & & & & & & & & & & \\
\hline Rachitis & K & & & & & & & & & & & & \\
\hline
\end{tabular}


Table 2 The unique uses of Aloes in the study area with reference to ethnic group. The uses are categorized into seven groups of use. Species are presented sequential from the most to the least used. K-Kamba, Ki-Kikuyu, Kii-Kisii, Ma-Maasai, Mb-Mbeere, Sa-Samburu, So-Somali, T- Taita, Tu- Tugen (Continued)

\begin{tabular}{|c|c|c|c|c|c|c|c|c|c|}
\hline Ringworm & K, So, T & & & & & & & & \\
\hline Stiff muscles & K & & & & & & & & \\
\hline $\begin{array}{l}\text { Stomach ache, } \\
\text { Diaphragm problems }\end{array}$ & $\mathrm{Ma}, \mathrm{Sa}, \mathrm{K}, \mathrm{T}$ & & & & & & & & \\
\hline Swelling of legs & $\mathrm{K}, \mathrm{Ma}$ & & & & & & & & \\
\hline Tuberculosis & Ma & & & & & & & & \\
\hline Typhoid & Ma & & & & & & & & \\
\hline Ulcer, boils & K, So, Tu & & & & & & & & \\
\hline Vomiting & Ma, So, & & & & & & & & \\
\hline Wounds (cleaning fresh -) & $\mathrm{Ma}, \mathrm{Sa}, \mathrm{T}$ & & & & & & & & \\
\hline \multicolumn{10}{|l|}{ A. volkensii Engl. } \\
\hline \multirow[t]{3}{*}{ Pneumonia } & Ma & $\begin{array}{l}\text { east coast fever, } \\
\text { goats }\end{array}$ & $\mathrm{Ma}$ & browsed by goats $\mathrm{Ma}$ & boundaries & Ma & Beer Ma & $\begin{array}{l}\text { gums for } \\
\text { arrows }\end{array}$ & $\mathrm{Ma}$ \\
\hline & & wounds, cattle & Ma & & $\begin{array}{l}\text { fences, } \\
\text { hedging }\end{array}$ & Ma & & & \\
\hline & & & & & $\begin{array}{l}\text { wind } \\
\text { breaking }\end{array}$ & Ma & & & \\
\hline \multicolumn{10}{|l|}{ A. ukambensis Reynolds } \\
\hline Diaphragm & K & chicken diseases & K & & & & & & \\
\hline Malaria & K & & & & & & & & \\
\hline
\end{tabular}


of uses documented for it. A species' range is also correlated with the number of ethnic groups that may use a species; in this study, A. lateritia and A. secundiflora were used by 8 and 7 ethnic groups, respectively (Fig. 2). At the other end of the scale, about $50 \%$ of the species were used by only one ethnic group. In our study area, 16 of a total of 19 species were used (84\%), in contrast to the overall use in Kenya where only 23 out of 63 species of Aloe (37\%) are documented to be used. We propose that this disparity is due to the high number of rare species of Aloe in Kenya, which are often found in remote areas. In inhabited areas, the aloes undoubtedly play a very important role for the society, people and their livestock.

\section{Conclusions}

Aloes are very important plants of use in Kenya. Their value is evident in the shared knowledge and use practices for species of Aloe throughout communities, regardless of age, gender, ethnic belonging, and place of residence. The ethnobotanical genus and species delimitation coincides with the scientific species concepts, while vernacular naming is closely linked to use and validates the use of vernacular nomenclature as a simple proxy for plant value. In Kenya, $37 \%$ of Aloe species are used, of which the most important are the widespread Aloe secundiflora and $A$. lateritia and the most common uses, amongst all ethnic groups, are the treatment of malaria and poultry diseases. These findings agree remarkably with findings of studies in other regions of the Aloe distribution [4].

The use and exploitation of natural resources is often regarded as a threat to plant populations if the sustainability of harvesting practices has not been assessed. Illegal commercial harvesting is a grave threat to Aloe species in Kenya, whereas wild harvesting for local uses appears to be sustainable at current levels. The availability of useful Aloe species appears to be impacted more immediately by habitat loss, and species' value has stimulated protection and propagation measures on a local scale.

\section{Competing interests}

The authors declare that they have no competing interests.

\section{Authors' contributions}

CSB, EW, IN \& LEN designed the study. EW, CSB conducted field work. EW, LN added additional data, CSB prepared the statistical analyses, CSB coordinated the manuscript writing with major input from OMG, IN, EW\& LEN. All authors read and approved the final manuscript.

\section{Acknowledgements}

We are indebted to various people and institutions for the implementation of this study: The East African Herbarium, Nairobi (EA) for kind support, Mathias M. Mbale for tireless enthusiasm and technical support in the field. Thanks to Prof. Rune Halvorsen for assistance with the statistical analyses and Thomas Henden for scanning slides. Many thanks also to Maria Dodds and her family for generously hosting us. Thanks to two anonymous referees whose comments lead to considerable improvement. The bulk of this research was undertaken with funds from the Norwegian Council of Universities' Committee for Development and Education (NUFU project 53/3) and the Norwegian Research Council (project 151050).

\section{Author details}

${ }^{1}$ Natural History Museum, University of Oslo, P.O. Box 1172, Blindern 0318 Oslo, Norway. ${ }^{2}$ Department of Bioscience, University of Oslo, P.O. Box 1066, Blindern 03160slo, Norway. ${ }^{3}$ Department of Plant Sciences, Kenyatta University, P.O. Box 43844, Nairobi 00100, Kenya. ${ }^{4}$ Comparative Plant \& Fungal Biology, Royal Botanic Gardens, Kew, Surrey TW9 3AB, UK.

Received: 6 October 2015 Accepted: 13 October 2015

Published online: 25 November 2015

\section{References}

1. Morton JF. Folk uses and commercial exploitation of Aloe leaf pulp. Econ Bot. 1961;36:311-9.

2. Crosswhite FS, Crosswhite CD. Aloe vera, plant symbolism and the threshing floor: light, life and good in our heritage. Desert Plants. 1984;6:43-50.

3. Atherton P. First aid plant. Chem Brit. 1998;34:33-6.

4. Grace OM, Simmonds MSJ, Smith GF, Van Wyk AE. Documented utility and biocultural value of Aloe L. (Asphodelaceae): a review. Econ Bot. 2009;63:167-78.

5. Rowley GD. A History of Succulent Plants. Mill Valley: Strawberry Press; 1997.

6. Carter S, Lavranos JJ, Newton LE, Walker CC. Aloes: The Definitive Guide. Royal Botanic Gardens. Kew: Kew Publishing; 2011.

7. Grace OM. Current perspectives on the economic botany of the genus Aloe L. (Xanthorrhoeaceae). S Afr J Bot. 2011;77:980-7.

8. Carter S. Aloaceae. In: Polhill RM, editor. Flora of Tropical East Africa. Rotterdam: Balkema, Rotterdam; 1994. p. 1-67.

9. Eggli U, Newton LE, Rowley GD. CITES Aloe and Pachypodium checklist. Royal Botanic Gardens. Kew: Kew Publishing; 2001.

10. Newton LE. Aloe. In: Eggli U, editor. Illustrated Handbook of Succulent Plants, Monocotyledons. Berlin: Springer; 2001. p. 102-223.

11. Wabuyele E, Bjorå CS, Nordal I, Newton LE. Distribution, diversity and conservation of the genus Aloe in Kenya. J East Afr Nat Hist Soc. 2006;95:213-25.

12. McCoy T, Lavranos JJ. Two significant new aloes from Kenya. Cact World 2007;25:209-11.

13. Newton LE. Two new species of Aloe in Kenya. Bradleya. 2011;29:57-60.

14. Wabuyele E, Kyalo S. Sustainable Use of East African Aloes: The case of Commercial Aloes in Kenya. 2008. https://cites.unia.es/file.php/1/files/ WG3-CS1.pdf. Accessed 1 Sept 2015.

15. Tambo OHA. A phytochemical investigation of three species of Aloe selected for possible commercial exploitation. M.Sc thesis. Nairobi: Kenyatta University; 1991.

16. Oldfield S. Review of Significant Trade East African Aloes. CITES; 2003. PC14 Do. 9.2.2 Annex 4. https://cites.org/sites/default/files/eng/com/pc/14/EPC14-09-02-02-A4.pdf

17. Lubia IK, Kyalo SN, Mukonyi KW, Lusweti AM, Situma CA. Strategy for conservation and management of commercial Aloe species in Kenya. Kenya Wildlife Report. 2008. www.kws.go.ke/download/file/fid/1405. Accessed 1 Sept 2015

18. Nyamora P. Medicinal plant given presidential protection. Daily Nation (Kenya). 1986;8075:1-24.

19. Newton LE. Exploitation and conservation of Aloes in Kenya. Malawi: In Proceedings of. XIllth Plenary meeting of AETFAT; 1994.

20. Anonymous. Wildlife (Conservation and management) (Aloe species) Regulations. 2007 [L.N. 403/2007]. http://faolex.fao.org/docs/pdf/ken101511.pdf. Accessed 1 Sept 2015

21. Mukoyon KW, Owuor B, Chikamai BN, Wabuyele E. A review and appraisal of the Aloe recourses in Kenya; utilization and development status. July: KEFRI Report; 2001.

22. Newton LE. Succulent Plant Utilisation and Conservation in Eastern Tropical Africa. In: Russo L, editor. Proceedings of The Succulent Plants of Eastern Africa: History, Botanical Exploration and Research. 2004.

23. Newton LE. Goodbye to the type locality of Aloe ballyi. A sad tale of habitat destruction in Kenya. CactusWorld. 2007;25:45-6.

24. The IUCN red list of treatened species. http://www.iucnredlist.org/search. Accessed Jan 2015 
25. Holman EW. The relation between folk and scientific classification of plants and animals. J Classif. 2002;19:131-59.

26. Grace OM, Simmonds MSJ, Smith GF, Van Wyk AE. Therapeutic uses of Aloe L. (Asphodelaceae) in Southern Africa. J Ethnopharmacol. 2008;119:604-14.

27. Neuwinger HD. Afrikanische Arzneipflanzen und Jagdgifte Chemie, Pharmakologie, Toxikologie. Stuttgart: Wissenschaftliche Verlagsgesellschaft $\mathrm{mbH} ; 1994$.

28. Oketch-Rabah HA, Dossaji SF, Mberu EK. Antimalarial activity of some Kenyan medicinal plants. Pharm Biol. 1999;37:329-34.

29. Waihenya RK, Mtambo MMA, Nkwenguila G, Minga UM. Efficacy of crude extract of Aloe secundiflora against Salmonella gallinarum in experimentally infected free-range chickens in Tanzania. J Ethnopharmacol. 2002;79:317-23.

30. Hindmarsh L. A notebook for Kenyan Dyers. National Museum of Kenya: Nairobi; 1982.

31. Kokwaro JO. Medicinal plants of East Africa. 2nd ed. Kenya Literature Bureau Nairobi; 1993.

32. Maundu PM, Ngugi GW, Kabuye CHS. Traditional Food Plants of Kenya. National Museum of Kenya: Nairobi; 1999.

33. Anonymous. $R$ version 3.1.2 for Windows. The $R$ foundation for statistical computing; 2014. http://cran.r-project.org.

34. Morgan WTW. Ethnobotany of the Turkana: use of plants by a pastoral people and their livestock in Kenya. Econ Bot. 1981;35:96-130.

35. Bussmann RW. Ethnobotany of the Samburu of Mt. Nyiru, South Turkana, Kenya. J Ethnobiol Ethnomed. 2006;2:35.

36. Grade JT, Tabuti JRS, Van Damme P. Ethnoveterinary knowledge in pastorial Karamoja Uganda. J Ethnopharmacol. 2009:122:273-93.

37. Jeruto P, Lukhoba C, Ouma G, Otieno D, Mutai C. An ethnobotanical study of medicinal plants used by the Nandi people in Kenya. J Ethnopharmacol. 2007;116:370-6.

38. Grace OM, Buerki S, Symonds MRE, Forest F, van Wyk AE, Smith GF, et al. Evolutionary history and leaf succulence as explanations for medicinal use in aloes and the global popularity of Aloe vera. BMC Evol Biol. 2015;15:29.

\section{Submit your next manuscript to BioMed Central and take full advantage of:}

- Convenient online submission

- Thorough peer review

- No space constraints or color figure charges

- Immediate publication on acceptance

- Inclusion in PubMed, CAS, Scopus and Google Scholar

- Research which is freely available for redistribution 